\title{
Analisis Beban Kerja Dan Jumlah Tenaga Kerja Pada Bagian Bahan Baku Menggunakan Metode Workload Analysis
}

\author{
Candrianto $^{1}$, Radna Ningsih ${ }^{1}$, Alpon Satrianto ${ }^{2}$, Rizki Fadhillah Lubis ${ }^{3}$ \\ ${ }^{1}$ Program Studi Manajemen Logistik Industri Agro, Politeknik ATI Padang, Jalan Bungo Pasang Tabing, Padang, 25171, Indonesia \\ ${ }^{2}$ Universitas Negeri Padang, Jalan Prof. Dr. Hamka, Air Tawar Padang, Indonesia \\ ${ }^{3}$ Program Studi Teknik Industri Agro, Politeknik ATI Padang, Jalan Bungo Pasang Tabing, Padang, 25171, Indonesia
}

\section{ARTICLE INFORMATION}

Received: June 01, 2020

Revised: June 24, 2020

Accepted: June 28, 2020

\section{KEYWORD}

Workload,

Workload Analisys

\section{CORRESPONDENCE}

Name: Candrianto

E-mail: candriantokemenperin@gmail.com

\section{A $\quad$ B $\quad S \quad T \quad R A$ C $\mathbf{T}$}

This research was conducted at PT. XYZ in the garden section, a company engaged in the forestry sector of industrial plants and products that produce HVS paper (such as paper one, otc), paperboard, kiky books, tissue (teas). PT.XYZ manages raw materials that are not in accordance with the target, the purpose of this study is to determine the amount of workload and the number of workers in the garden section at PT. XYZ. To collect the data needed in this study, data collection techniques were used through direct observation of the object under study, interviews and various other reference sources. Data analysis using the Workload Analysis method. From the results of calculations using the method, workload is one aspect that must be considered by every company, and workload must be considered for a worker to get harmony and high work productivity. By using the Workload Analysis method and to find out how much the optimal number of workers is in the raw material section. After analyzing the data using this analysis, it can be obtained that the average workload on the raw material section is $184.39 \%$, which means that the workload is excessive. In order for the workload of each workforce in the garden to be optimal, it is advisable to increase the workload with an average workload of $92.19 \%$ so that effectiveness can be achieved.

\section{PENDAHULUAN}

Pekerjaan merupakan beban bagi yang menjalaninya seperti beban fisik dan mental. Dari sudut pandang ergonomi, beban kerja yang diterima harus sesuai baik terhadap kemampuan fisik maupun keterbatasan manusia yang menerima beban tersebut. Beban kerja yang melampaui kemampuan kerja tentu akan menimbulkan dampak yang buruk sepertisuasana kerja yang kurang nyaman bagi pekerja karena dapat memicu timbulnya stres kerja yang lebih cepat. Sebaliknya kekurangan beban kerja dapat menimbulkan kerugian bagi organisasi (Arif, 2014, Prabowo, 2017). Analisis beban kerja merupakan metode yang biasa digunakan untuk menentukan jumlah atau kuantitas tenaga kerja yang diperlukan. Beban kerja yang didistribusikan secara tidak merata dapat mengakibatkan ketidaknyamanan suasana kerja karena karyawan merasa beban kerja yang dilakukannya terlalu berlebihan atau bahkan kekurangan (Wibawa, Sugiono, \& Efranto, 2014).
Beban kerja yang dibebankan pada pekerja terjadi dalam tiga kondisi yaitu beban kerja normal (fit), beban kerja berlebih (overload) dan beban kerja yang terlalu rendah (underload). Beban kerja yang terlalu berat atau terlalu ringan akan mengakibatkan terjadinya inefisiensi kerja. Beban kerja yang terlalu berlebih (overload) mengindikasikan bahwa jumlah pekerja yang dipekerjakan tidak sesuai dengan beban kerja yang diterima sehingga dapat menyebabkan kelelahan fisik maupun psikologis yang berakibat pada menurunnya produktivitas karena kelelahan bekerja. Sedangkan beban kerja yang terlalu rendah (underload) mengindikasikan bahwa jumlah pekerja yang dipekerjakan terlalu banyak sehingga perusahaan harus mengalokasikan biaya untuk gaji karyawan lebih banyak dengan tingkat produktivitas yang sama. Hal ini menyebabkan terjadinya inefisiensi biaya. Jadi, perlu kita menentukan beban kerja yang optimal bagi setiap pekerja dalam menyelesaikan pekerjaannya sehingga tidak menimbulkan bahaya baik untuk pekerja itu 
sendiri maupun perusahaan yang menggunakan jasa pekerja.

Permasalahan yang ada pada PT XYZ yang bergerak dibidang kehutanan tanaman industri, memiliki 12 sektor tempat pengolahan bahan baku adalah tenaga kerja yang sedikit dengan beban kerja yang tinggi dimana tenaga kerjanya terdiri dari pekerja 1, pekerja 2 dan pekerja 3 . Beban kerja yang tidak optimal dibuktikan dengan jumlah tenaga kerja pada bagian bahan baku tidak sesuai dengan standar. Pada tahun 2018 jumlah tenaga kerja PT. XYZ sebanyak 4.601 orang seperti terlihat pada tabel 1 dbawah ini:

Tabel 1. Jumlah Tenaga Kerja Berdasarkan Jenis Kelamin PT. XYZ Tahun 2017-2018

\begin{tabular}{|c|c|c|c|c|}
\hline \multirow{2}{*}{ No } & \multirow{2}{*}{ Tahun } & \multicolumn{2}{|c|}{ Tenaga Kerja (Orang) } & \multirow{2}{*}{$\begin{array}{l}\text { Jumlah } \\
\text { (Orang) }\end{array}$} \\
\hline & & Pria & Wanita & \\
\hline 1 & 2017 & 3.117 & 2.000 & 5.117 \\
\hline 2 & 2018 & 2.801 & 1.800 & 4.601 \\
\hline
\end{tabular}

Sumber: PT.XYZ

Sedangkan luas kebun tempat menanam bahan baku sebesar 15.809 Ha. Ini di perlukan adanya pengukuran terhadap beban kerja di bagian bahan baku sehingga dapat di ketahui berapa jumlah tenaga kerja dan berapa waktu penyelesaian pekerjaan oleh setiap pekerja sehingga tidak terjadi kelebihan beban kerja atau kelebihan jumlah tenaga kerja. Metode yang digunakan dalam penelitian ini adalah metode Workload Analysis.

\section{METODOLOGI}

Penelitian ini menganalisis tentang beban kerja yang dialami oleh pekerja pada bagian bahan baku dengan menggunakan metode Workload Analysis dan menentukan jumlah pekerja optimal yang seharusnya dipekerjakan. Langkah - langkah yang dilakukan dalam melakukan penelitian ini adalah sebagai berikut:

\section{Lokasi dan Waktu Penelitian}

Penelitian ini dilaksanakan di PT. XYZ pada bagian bahan baku, Jl. Raya PKU, Teluk Kuantan, Simpang Petai, Singingi Hilir., Indonesia.

\section{Populasi dan Sampel}

Populasi dan sampel adalah pekerja yang di bagian bahan baku yang terdiri dari pekerja 1, pekerja 2 dan pekerja 3 .

\section{Metode Pengumpulan Data}

Yang digunakan adalah dokumentasi dan wawancara. Dokumentasi dilakukan dengan cara mengumpulkan data atau dokumen terkait penelitian dan wawancara dilakukan dengan memberikan pertanyaan-pertanyaan kepada bagian bahan baku.

\section{Analisis Data}

Data-data yang akan dianalisis berupa penyebab besarnya beban kerja serta menentukan solusi perbaikan untuk menurunkan beban kerja yang tinggi meliputi struktur organisasi dan job description tiap jabatan, aktivitas dan waktu penyelesaian aktivitas-aktivitas tersebut dikelompokan pada job description yang dilakukan oleh aktivitas terkait, menghitung besarnya persentase produktif dan non produktif., menentukan jumlah menit pengamatan, penentuan Allowance dan Performance Rating serta perhitungan besarnya beban kerja dengan menggunakan rumus :

Beban kerja $=\%$ Produktif $x$ Perfomance Rating $(1+$ Allowance)

\section{Uji Keseragaman Data}

Pengujian ini dilakukan untuk mengetahui apakah data yang didapatkan telah seragam dan tidak melebihi dari batas kotrol atas (BKA) dan batas kontrol bawah (BKB) yang telah ditentukan. Rumus-rumus untuk menentukan batas kontrol menurut Wignjosoebroto (2003:215) yaitu:

Dimana $P$ adalah: $\mathrm{BKB}=\mathrm{P}+3 \sqrt{\frac{p(1-p)}{n}}$

$\mathrm{P}=\frac{\sum \mathrm{pi}}{\mathrm{k}}$

$\mathrm{BKB}=\mathrm{P}-3 \sqrt{\frac{p(1-p)}{n}}$

Dengan Pi adalah persentase produktif di hari ke-i dan $\mathrm{k}$ adalah jumlah hari pengamatan

$\mathrm{n}=\frac{\sum p i}{k}$

dengan pi adalah jumlah pengamatan yang dilakukan di hari-i

\section{Uji Kecukapan Data}

Penguji ini dilakukan untuk mengetahui banyaknya pengamatan yang harus dilakukan dalam sampling pekerjaan, untuk mendapatkan jumlah sampel pengamatan yang harus dilaksanakan dapat di cari berdasarkan rumus oleh (Wignjosoebroto, 2003):

$\mathrm{N}^{\prime}=\frac{K^{2}(1-P)}{S^{2} p}$

Dimana:

$\mathrm{N}^{\prime}=$ jumlah pengamatan yang harus dilakukan untuk sampling kerja

$\mathrm{N}=$ Jumlah pengamatan yang telah dilakukan untuk sampling kerja

$\mathrm{S}=$ Koefisien Tingkat Ketelitian

$\mathrm{P}=$ Persentase produktif Rata- rata

$\mathrm{K}=$ Harga indeks yang besarnya tergantung dari tingkat kepercayaan yang diambil, yaitu:

Untuk Tingkat Kepercayaan $68 \% \mathrm{k}=1$

Untuk Tingkat Kepercayaan $95 \%$ k=2

Untuk Tingkat Kepercayaan $99 \%$ k=3

Dimana penentuan kecukupan data, yaitu sebagai berikut: 
a) Jika $\mathrm{N}<\mathrm{N}$ ' maka jumlah pengamatan yang dilakukan dinyatakan tidak cukup.

b) Jika $\mathrm{N}<\mathrm{N}$ ' maka jumlah pengamatan yang dilakukan dinyatakan cukup.

\section{Pengukuran Performance Rating}

Mencari Pi dengan menjumlah keempat rating faktor yang dipilih sesuai dengan performance yang ditunjukkan oleh operator berdasarkan tabel performance rating lalu menentukan nila $\mathrm{P}$ dengan rumus:

$\mathrm{P}=\mathrm{PO}+\mathrm{Pi}$, dimana $\mathrm{PO}=1$

\section{Perhitungan Jumlah Tenaga Kerja Sesuai Beban Kerja}

Adapun rumus untuk menentukan tenaga kerja yang sesuai adalah sebagai berikut:

Rata-rata beban kerja (existing) $=\frac{\text { Total Beban Kerja }}{\text { Jumlah Pekerjaan }}$

\section{Rekomendasi Penurunan Beban Kerja}

Adapun rumus untuk penurunan beban kerja adalah sebagai berikut:

$$
\text { Rata-rata beban kerja }=\frac{\text { Total Beban Kerja }}{\text { Jumlah Pekerjaan Rekomendasi }}
$$

\section{HASIL DAN PEMBAHASAN}

PT XYZ menyediakan bahan baku kayu yang akan di olah menjadi bahan setengah jadi yang akan di kirim ke pabrik pengolahan kertas seperti PT RAPP. Pekerjaan yang dilakakuan pada bagian bahan baku ini tidak dikerjakan individual, melainkan bersama (team). Pengerjaan di mulai dari menanam pohon ecalutis dan ecaasia setelah itu merawat ecalitus dan ecaasia supaya rumput sekitar tidak akan menganggu pertumbuhan pada pohon tersebut. Pada bagian bahan baku ini memiliki 3 orang tenaga kerja yaitu menanam bahan baku, merawat bahan baku dan pemanenan pada bahan baku. PT XYZ memiliki tenaga kerja harian dan tenaga kerja Staff. Pada umumnya hari kerja dimulai pada hari Senin sampai Sabtu tanpa ada libur, kecuali libur hari besar agama dan tanggal merah dengan rata-rata jam kerja 7 jam/hari, seperti terlihat pada tabel 2 dibawah ini :

Tabel 2. Jumlah Jam Kerja PT XYZ

\begin{tabular}{lllllll}
\hline Keterangan & Senin (Wib) & Selasa (Wib) & Rabu (Wib) & Kamis (Wib) & Jum'at (Wib) & Sabtu (Wib) \\
\hline Masuk & 07.00 & 07.00 & 07.00 & 07.00 & 07.00 & 07.00 \\
Istirahat & $11.30-13.30$ & $11.30-13.30$ & $11.30-13.30$ & $11.30-13.30$ & $11.30-13.30$ & - \\
Keluar & 16.00 & 16.00 & 16.00 & 16.00 & 16.00 & 12.00 \\
\hline
\end{tabular}

Pengamatan aktivitas bahan baku dari tabel frekuensi, pengamatan dilakukan selama 30 hari kerja. Teknis pengamatan yang dilakukan setiap menanam bahan baku ecalitus dan acaasia sehingga pemanenan pada bahan baku tersebut. Laporan waktu pengerjaan tiap aktivitas bahan baku terlihat pada tabel 3 dan tabel 4 dibawah ini:

Tabel 3. Waktu Pengerjaan Tiap Aktivitas di KebunPT. XYZ

\begin{tabular}{cllccc}
\hline \multirow{2}{*}{ No } & \multirow{2}{*}{ Keterangan } & \multicolumn{1}{c}{ Aktivitas } & $\begin{array}{c}\text { Jumlah } \\
\text { Aktivitas (kali) }\end{array}$ & $\begin{array}{c}\text { Wakltu Siklus } \\
\text { (menit) }\end{array}$ & $\begin{array}{c}\text { Total Waktu } \\
\text { Siklus (menit) }\end{array}$ \\
\hline 1 & Produktif & Menyiapkan lahan untuk menanam & 7 & 3 & 21 \\
2 & Produktif & Menanam bahan baku & 6 & 4 & 24 \\
3 & Produktif & Memeriksa kondisi bahan baku & 13 & 4 & 52 \\
4 & Produktif & Memeriksa kondisi mesin & 10 & 3 & 30 \\
5 & Produktif & Permanen & 8 & 4 & 32 \\
6 & Produktif & Membuat laporan & 1 & 4 & 22 \\
\hline & & Total & 45 & 3 & 163 \\
\hline 7 & Non Produktif & Kegiatan diluar job desc & 5 & 25 & 190 \\
\hline & & Total & 54 & & 27 \\
\hline
\end{tabular}

Dari tabel 3, waktu pengerjaan tiap aktivitas pada kebun ada sebanyak 7 aktivitas yang pertama menyiapkan bahan baku jumlah aktivitasnya 3 kali, waktu siklusnya 3 menit dengan total waktu siklusnya 9 menit, yang kedua menanam bahan baku yang memiliki jumlah aktivitasnya 3 kali, waktu siklusnya 4 menit, dengan jumlah total waktu siklusnya 12 menit, yang ketiga mencek kondisi bahan baku jumlah aktivitasnya 8 kali, waktu siklusnya 4 menit, dengan total waktu siklusnya 32 menit, keempat mencek kondisi mesin jumlah aktivitas 6 kali, waktu siklus 3 menit dengan total waktu siklusnya 18 menit, ke lima pemanenan

38 Candrianto et al. yang jumlah aktivitasnya 3 kali, waktu siklusnya 4 menit dengan total waktu siklusnya 4 menit, keenam membuat laporan jumlah aktivitasnya 1 kali, waktu siklusnya 4 menit, dengan total waktu siklusnya 4 menit, ketujuh kegiatan diluar job disk, jumlah aktivitasnya 6 kali, waktu siklus 3 menit dengan total waktu siklusnya 3 menit. Dari seluruh kegiatan tersebut total waktu siklus yang digunakan untuk menjalankan pekerjaan adalah 190 menit. Sedangkan pada tabel 4 dibawah ini adalah aktivitas pengamatan yang dilakukan pada kebun PT.XYZ seperti dibawah ini: 
Tabel 4. Matriks Pengamatan Aktivitas Kebun PT XYZ, Tahun 2018

\begin{tabular}{|c|c|c|c|c|c|c|c|c|c|}
\hline \multirow{2}{*}{$\begin{array}{c}\text { Tanggal } \\
\text { Pengamatan }\end{array}$} & \multirow{2}{*}{$\begin{array}{c}\text { Hari } \\
\text { Pengamatan }\end{array}$} & \multicolumn{8}{|c|}{ Jumlah Satuan (Kali) } \\
\hline & & Aktivitas 1 & Aktivitas & 2 Aktivitas 3 & Aktivitas 4 & Aktivitas & 5 Aktivitas 6 & $\begin{array}{c}\text { Total } \\
\text { Produktif }\end{array}$ & $\begin{array}{c}\text { Kegiatan Non } \\
\text { Produktif } \\
\end{array}$ \\
\hline $23 / 07 / 2018$ & $\mathrm{Ke}-1$ & 20 & 30 & 15 & 19 & 30 & 19 & 113 & 15 \\
\hline 24/07/2018 & $\mathrm{Ke}-2$ & 16 & 25 & 13 & 18 & 30 & 17 & 119 & 12 \\
\hline $25 / 07 / 2018$ & $\mathrm{Ke}-3$ & 15 & 30 & 17 & 21 & 25 & 19 & 127 & 14 \\
\hline 26/07/2018 & $\mathrm{Ke}-4$ & 19 & 25 & 15 & 18 & 27 & 20 & 124 & 18 \\
\hline 27/07/2018 & $\mathrm{Ke}-5$ & 19 & 25 & 15 & 16 & 28 & 24 & 127 & 12 \\
\hline 28/07/2018 & Ke-6 & 18 & 20 & 26 & 22 & 26 & 19 & 131 & 15 \\
\hline $30 / 07 / 2018$ & $\mathrm{Ke}-7$ & 17 & 30 & 16 & 18 & 30 & 20 & 131 & 14 \\
\hline $31 / 07 / 2018$ & $\mathrm{Ke}-8$ & 20 & 25 & 18 & 16 & 28 & 15 & 122 & 16 \\
\hline 01/08/2018 & $\mathrm{Ke}-9$ & 18 & 26 & 26 & 19 & 26 & 17 & 132 & 13 \\
\hline 02/08/2018 & $\mathrm{Ke}-10$ & 15 & 27 & 25 & 19 & 28 & 16 & 130 & 15 \\
\hline 03/08/2018 & $\mathrm{Ke}-11$ & 18 & 28 & 19 & 21 & 24 & 26 & 136 & 12 \\
\hline 04/08/2018 & $\mathrm{Ke}-12$ & 19 & 30 & 20 & 18 & 26 & 15 & 128 & 15 \\
\hline 06/08/2018 & $\mathrm{Ke}-13$ & 24 & 28 & 19 & 18 & 30 & 19 & 138 & 14 \\
\hline 07/08/2018 & $\mathrm{Ke}-14$ & 19 & 29 & 20 & 20 & 27 & 18 & 133 & 15 \\
\hline 08/08/2018 & $\mathrm{Ke}-15$ & 21 & 26 & 19 & 21 & 28 & 18 & 133 & 10 \\
\hline 09/08/2018 & $\mathrm{Ke}-16$ & 15 & 27 & 25 & 28 & 27 & 19 & 141 & 17 \\
\hline $10 / 08 / 2018$ & $\mathrm{Ke}-17$ & 27 & 30 & 21 & 19 & 30 & 18 & 145 & 14 \\
\hline $11 / 08 / 2018$ & $\mathrm{Ke}-18$ & 21 & 25 & 18 & 19 & 28 & 16 & 127 & 19 \\
\hline $13 / 08 / 2018$ & Ke-19 & 26 & 28 & 23 & 25 & 25 & 20 & 147 & 16 \\
\hline $14 / 08 / 2018$ & $\mathrm{Ke}-20$ & 22 & 27 & 15 & 18 & 27 & 21 & 130 & 12 \\
\hline $15 / 08 / 2018$ & $\mathrm{Ke}-21$ & 24 & 30 & 25 & 20 & 26 & 18 & 143 & 15 \\
\hline $16 / 08 / 2018$ & $\mathrm{Ke}-22$ & 22 & 26 & 29 & 22 & 25 & 20 & 134 & 17 \\
\hline $17 / 08 / 2018$ & $\mathrm{Ke}-23$ & 19 & 25 & 21 & 22 & 28 & 23 & 138 & 19 \\
\hline $18 / 08 / 2018$ & $\mathrm{Ke}-24$ & 18 & 30 & 16 & 23 & 26 & 17 & 130 & 15 \\
\hline 20/08/2018 & $\mathrm{Ke}-25$ & 14 & 27 & 15 & 19 & 24 & 15 & 114 & 21 \\
\hline 21/08/2018 & $\mathrm{Ke}-26$ & 19 & 25 & 20 & 24 & 26 & 21 & 135 & 18 \\
\hline $22 / 08 / 2018$ & $\mathrm{Ke}-27$ & 21 & 30 & 19 & 15 & 25 & 19 & 129 & 15 \\
\hline $23 / 08 / 2018$ & $\mathrm{Ke}-28$ & 25 & 27 & 20 & 18 & 30 & 20 & 140 & 18 \\
\hline 24/08/2018 & $\mathrm{Ke}-29$ & 24 & 28 & 18 & 26 & 30 & 22 & 148 & 19 \\
\hline 25/08/2018 & $\mathrm{Ke}-30$ & 28 & 30 & 26 & 16 & 27 & 18 & 145 & 20 \\
\hline \multicolumn{2}{|c|}{ Total } & 603 & 819 & 584 & 598 & 817 & 569 & 3990 & 465 \\
\hline
\end{tabular}

\section{Keterangan:}

Aktivitas 1: Menyiapkan lahan untuk menanam

Aktivitas 2: Menanam bahan baku

Aktivitas 3: Mencek kondisi bahan baku

Aktivitas 4: Mencek kondisi mesin

Aktivitas 5: Pemanenan

Aktivitas 6: Membuat laporan

Dari tabel 4 diatas, Matriks pengamatan aktivitas bahan baku ini dengan pengamatan selama 30 hari, disini ada enam aktivitas yang aktivitas pertama memiliki total dalam 30 hari tersebut sebanyak 603 hari, aktivitas ke dua dengan total aktivitas 819 hari, aktivitas ke tiga memiliki total aktivitas 584 kali, aktivitas ke empat dengan total aktivitas 598 kali, aktivitas ke lima memiliki jumlah total aktivitas 817 kali, dan aktivitas ke enam ini total aktivitas 569 kali. Dengan keseluruhan masing-masingnya memiliki total produksi selama 30 hari tersebut sebesar 3.990 kali aktivitas sedangkan untuk mendapatkan kegiatan di luar dari produksi dengan totalnya 465 kali. Jadi untuk memdapatkan jumlah keseluruhan dari aktivitas yang dilakukan baik aktivitas produktif dan non produktif dengan total aktivitas sebanyak 4.445 kali selama 30 hari. Pada tabel 5 dibawah ini akan disajikan rekapitulasi aktivitas kebun selama 30 hari sebagai berikut:

Tabel 5. Rekapitulasi Aktivitas Kebun

\begin{tabular}{|c|c|c|c|c|}
\hline No & Keterangan & Aktivitas & $\begin{array}{c}\text { Aktivitas } \\
\text { (hari) }\end{array}$ & $\begin{array}{c}\text { Proporsi } \\
\text { kerja (kali) }\end{array}$ \\
\hline 1 & Produktif & $\begin{array}{l}\text { Menyiapkan lahan } \\
\text { untuk menanam }\end{array}$ & 603 & 14 \\
\hline 2 & Produktif & Menanam bahan baku & 819 & 18 \\
\hline 3 & Produktif & $\begin{array}{l}\text { Memeriksa kondisi } \\
\text { bahan baku }\end{array}$ & 584 & 13 \\
\hline 4 & Produktif & $\begin{array}{l}\text { Memeriksa kondisi } \\
\text { mesin }\end{array}$ & 598 & 13 \\
\hline 5 & Produktif & Permanen & 817 & 18 \\
\hline \multirow[t]{2}{*}{6} & Produktif & Membuat laporan & 569 & 13 \\
\hline & & Total & 3990 & 90 \\
\hline \multirow[t]{2}{*}{7} & $\begin{array}{l}\text { Non } \\
\text { produktif }\end{array}$ & $\begin{array}{l}\text { Kegiatan diluar job } \\
\text { desc }\end{array}$ & 427 & 10 \\
\hline & & Total & 4417 & 99 \\
\hline
\end{tabular}

Dari tabel 5 diatas, menjelaskan tentang jumlah aktivitas bagian bahan baku yang mana menganalisis aktivitas selama 30 hari masing-masingnya yang pertama menyiapkan lahan untuk menanam jumlahnya 603 hari dengan proporsi kerja 14 kali, kedua menanam bahan baku 
jumlahnya 819 hari dengan proporsi kerja 18 kali, ketiga mencek kondisi bahan baku jumlahnya 584 hari dengan proporsi kerja 13 kali, keempat mencek kondisi mesin jumlahnya 598 hari dengan proporsi kerja 13 kali, ke lima pemanenan jumlahnya 817 hari dengan proporsi kerjanya 18 kali, keenam membuat laporan jumlahnya 569 hari, dengan proporsi kerjanya13 kali sedangkan jumlah kegiatan di luar job desk memiliki aktivitas 427 hari dengan proporsi kerjanya 10 kali. Jadi, total keseluruhan dari aktivitas kebun sebanyak 4.417 hari dengan proporsi kerja sebanyak 99 kali. Kegiatan diluar jobdesk seperti minum, ngobrol, keperluan pribadi dan lain-lain.

\section{Uji Keseragaman dan Kecukupan Data}

Uji keseragaman data dan uji kecukupan data dilakukan dengan menggunakan tingkat ketelitian $10 \%$ dan tingkat kepercayaanya $95 \%$ perhitunganya terdapat pada tabel 6 adalah sebagai berikut:

Tabel 6. Frekuensi Pengamatan Proses Bahan Baku, PT. $\mathrm{XYZ}$

\begin{tabular}{|c|c|c|c|c|}
\hline \multirow[b]{2}{*}{$\begin{array}{c}\text { Hari } \\
\text { Pengamatan }\end{array}$} & \multicolumn{3}{|c|}{ Kegiatan } & \multirow[b]{2}{*}{$\begin{array}{l}\text { Produktif } \\
\quad(\%)\end{array}$} \\
\hline & $\begin{array}{c}\text { Produktif } \\
\text { (menit) }\end{array}$ & $\begin{array}{c}\text { Non } \\
\text { Produktif } \\
\text { (menit) }\end{array}$ & Jumlah & \\
\hline $\mathrm{Ke}-1$ & 133 & 15 & 148 & 90 \\
\hline $\mathrm{Ke}-2$ & 119 & 12 & 131 & 9 \\
\hline $\mathrm{Ke}-3$ & 127 & 14 & 141 & 90 \\
\hline $\mathrm{Ke}-4$ & 124 & 18 & 142 & 87 \\
\hline $\mathrm{Ke}-5$ & 127 & 12 & 139 & 91 \\
\hline $\mathrm{Ke}-6$ & 131 & 15 & 146 & 90 \\
\hline $\mathrm{Ke}-7$ & 131 & 14 & 145 & 90 \\
\hline $\mathrm{Ke}-8$ & 122 & 16 & 138 & 88 \\
\hline $\mathrm{Ke}-9$ & 132 & 13 & 145 & 91 \\
\hline $\mathrm{Ke}-10$ & 130 & 15 & 145 & 90 \\
\hline $\mathrm{Ke}-11$ & 136 & 12 & 148 & 92 \\
\hline $\mathrm{Ke}-12$ & 128 & 15 & 143 & 90 \\
\hline $\mathrm{Ke}-13$ & 138 & 14 & 152 & 91 \\
\hline $\mathrm{Ke}-14$ & 133 & 15 & 148 & 90 \\
\hline $\mathrm{Ke}-15$ & 133 & 10 & 143 & 93 \\
\hline $\mathrm{Ke}-16$ & 141 & 17 & 158 & 89 \\
\hline $\mathrm{Ke}-17$ & 145 & 14 & 159 & 91 \\
\hline $\mathrm{Ke}-18$ & 127 & 19 & 146 & 87 \\
\hline $\mathrm{Ke}-19$ & 147 & 16 & 163 & 90 \\
\hline $\mathrm{Ke}-20$ & 130 & 12 & 142 & 92 \\
\hline $\mathrm{Ke}-21$ & 143 & 15 & 158 & 91 \\
\hline $\mathrm{Ke}-22$ & 134 & 17 & 151 & 89 \\
\hline $\mathrm{Ke}-23$ & 138 & 19 & 157 & 88 \\
\hline $\mathrm{Ke}-24$ & 130 & 15 & 145 & 90 \\
\hline $\mathrm{Ke}-25$ & 114 & 21 & 135 & 84 \\
\hline $\mathrm{Ke}-26$ & 135 & 18 & 153 & 88 \\
\hline $\mathrm{Ke}-27$ & 129 & 15 & 144 & 90 \\
\hline $\mathrm{Ke}-28$ & 140 & 18 & 158 & 89 \\
\hline $\mathrm{Ke}-29$ & 148 & 19 & 167 & 89 \\
\hline $\mathrm{Ke}-30$ & 144 & 20 & 165 & 88 \\
\hline Jumlah & 3990 & 465 & 4.455 & 2.687 \\
\hline
\end{tabular}

Pada tabel 6 diatas, dapat dilihat bahwa pengamatan dilakukan selama 30 hari pengamatan. Jumlah aktivitas yang dilakukan oleh petugas bahan baku selama 30 hari pengamatan kemudian didapatkan rata-rata berapa kali kegiatan yang produktif, non produktif, jumlah total dan persentase produktif. Pengamatan ini dilakukan untuk menguraikan kegiatan produktif dan non produktif lalu mengetahui persentase produktif. Jumlah kegiatan produktif adalah 3.990 menit, sedangkan jumlah kegiatan non produktif adalah 465 menit dengan jumlah adalah 4.455 menit, dan persentase dari kegiatan produktif adalah $2.655 \%$.

\section{Uji Keseragaman Data}

Uji keseragaman data dilakukan untuk melihat apakah data yang ada berada didalam batas kontrol atas (BKA) dan batas kontrol bawah (BKB). Perhitungan uji keseragaman data sebagai berikut:

$$
\begin{aligned}
\mathrm{P} & =\frac{\sum \mathrm{pi}}{\mathrm{k}}=\frac{90 \%+91 \%+90 \%+\cdots . .+\cdots .+88 \%}{30} \\
& =89,5 \%=0,895 \\
\mathrm{n} & =\frac{\sum p i}{k}=\frac{148 \%+131 \%+141 \%+\cdots . .+\cdots .+165 \%}{30} \\
& =148,5 \%=1,485
\end{aligned}
$$

Untuk mendapatkan nilai dari $p$ didapatkan dari frekuensi pengamatan proses produksi yang di berjumlah 0,895 , sedangkan nilai $n$ didapatkan dari jumlah dari produktif dan non produktif yang mana nilai $n$ berjumlah 1,485.

$$
\begin{aligned}
\mathrm{BKA}= & \mathrm{P}+3 \cdot \sqrt{\frac{\mathrm{p}(1+\mathrm{p})}{n}} \\
& =0,895+3 \cdot \sqrt{ }(0,895(1+0,895)) / 148 \\
\mathrm{BKA} & =1,0161 \\
\mathrm{BKB}= & \mathrm{P}-3 \cdot \sqrt{ }(\mathrm{p}(1-\mathrm{p})) / \mathrm{N} \\
& =0,885-3 \cdot \sqrt{ }(0,895(1-0,895)) / 155 \\
\mathrm{BKB} & =0,6614
\end{aligned}
$$

Dari hasil perhitungan uji keseragaman data didapatkan angka untuk BKA mendapatkan hasil $=1,0161$ dan BKB = 0,6614 .

\section{Uji Kecukupan Data}

Setelah dilakukan uji keseragaman data, selanjutnya akan dilakukan perhitungan uji kecukupan data sebagai berikut: Dalam perhitungan kami menggunakan, Tingkat kepercayaan $=95 \%$

$\mathrm{K}=95 \%$, maka $\mathrm{K}=2$

Tingkat Ketelitian $=10 \%$

$\mathrm{P}=\frac{\Sigma \text { non produkstif }}{\Sigma n i}$

$$
=465 / 4455=0,10437710
$$

Uji kecukupan data

$$
\begin{aligned}
N^{\prime} & =0,10437710 \\
N^{\prime} & =(1-0,10437710) / 0,10437710 \\
& =8,58064556
\end{aligned}
$$

Dari uji kecukupan data didapatkan bahwa nilai $\mathrm{N}^{\prime}=$ 8,58064556 sedangkan $\mathrm{N}=4451$ yang mana $\mathrm{N}^{\prime}<\mathrm{N}$, maka dapat disimpulkan bahwa data sudah cukup dan tidak perlu dilakukan pengamatan tambahan lagi. 


\section{Perhitungan Beban Kerja Untuk Tenaga Kerja Bagian Kebun}

Untuk mengetahui beban kerja tiap - tiap elemen kerja maka harus diketahui Performance Rating dan Allowance untuk masing-masing elemen kerja. Perhitungan Performace Rating (Penyesuaian) dapat dilakukan dengan menjumlahkan faktor-faktor yang mempengaruhi kecepatan seseorang dalam melakukan pekerjaan dan ditambah nilai 1 . Nilai 1 (satu) ini suatu ketentuan dimana seseorang bekerja normal, sedangkan penentuan Allowance (Kelonggaran) dapat dilakukan dengan menjumlahkan faktor-faktor disesuaikan dengan tabel kelonggaran (riduwan, arif, 2008). Perhitungan pada Performance $=0,15+0,08+0,04+0,04=0,31$ jika nilai ditambah satu untuk ketentuan seseorang bekerja normal maka hasil nya yaitu 1,31 . Seperti pada tabel berikut adalah penyesuaian Performance Rating berdasarkan Westinghouse, terlihat pada tabel 7 dibawah ini:

Tabel 7. Performance Rating Berdasarkan Westinghouse

\begin{tabular}{|c|c|c|c|c|c|c|}
\hline \multirow[b]{2}{*}{ No } & \multirow[b]{2}{*}{$\begin{array}{c}\text { Jabatan } \\
\text { Struktural }\end{array}$} & \multicolumn{4}{|c|}{ Faktor } & \multirow{2}{*}{$\begin{array}{c}\text { Total } \\
\text { Perfor- } \\
\text { mance }\end{array}$} \\
\hline & & $\begin{array}{l}\text { Keteram- } \\
\text { pilan }\end{array}$ & Usaha & $\begin{array}{c}\text { Kondisi } \\
\text { Kerja }\end{array}$ & $\begin{array}{c}\text { Konsis- } \\
\text { tensi }\end{array}$ & \\
\hline 1 & $\begin{array}{l}\text { Tenaga } \\
\text { kerja } 1\end{array}$ & 0,15 & 0,08 & 0,04 & 0,04 & 1,31 \\
\hline 2 & $\begin{array}{l}\text { Tenaga } \\
\text { kerja } 2\end{array}$ & 0,11 & 0,08 & 0,04 & 0,04 & 1,27 \\
\hline 3 & $\begin{array}{l}\text { Tenaga } \\
\text { kerja } 3\end{array}$ & 0,15 & 0,05 & 0,04 & 0,04 & 1,28 \\
\hline
\end{tabular}

Berdasarkan tabel 7 diatas, terlihat Performance Rating berdasarkan Westinghouse untuk tenaga kerja 1 memiliki nilai 0,15 untuk ketrampilan, 0,08 untuk usaha, 0,04 untuk kondisi kerja dan konsistensi sehingga didapatkan performance ratingnya sebesar 1,31. Untuk tenaga kerja 2 memiliki nilai 0,11 untuk keterampilan, 0,08 untuk usaha, 0,04 untuk kondisi kerja dan konsistensi sehingga didapatkan Performance Rating nya sebesar 1,27. Untuk tenaga kerja 3, memiliki nilai 0,15 untuk keterampilan, 0,05 untuk usaha, 0,04 untuk kondisi kerja dan konsistensi sehingga didapatkan Performance Rating nya sebesar 1,28. Dari masing - masing jabatan struktural tenaga kerja mempunyai faktor - faktor dimana faktor ketrampilan, usaha, kondisi kerja, konsitensi didapatkan dari tabel Performance Rating berdasarkan Westinghouse nya. Sedangkan pada tabel berikut adalah penyesuaian Allowance berdasarkan faktor - faktor yang mempengaruhinya, seperti pada tabel 8 dibawah ini.

Tabel 8. Allowance Berdasarkan Faktor-Faktor yang Berpengaruh

\begin{tabular}{|c|c|c|c|c|c|c|c|c|c|c|}
\hline \multirow[b]{2}{*}{ No } & \multirow{2}{*}{$\begin{array}{c}\text { Jabatan } \\
\text { Struktural }\end{array}$} & \multicolumn{8}{|c|}{ Faktor Kelonggaran (\%) } & \multirow{2}{*}{$\begin{array}{c}\text { Total } \\
\text { Allowance }\end{array}$} \\
\hline & & A & B & $\mathrm{C}$ & $\mathrm{D}$ & $\mathrm{E}$ & $\mathrm{F}$ & G & $\mathrm{H}$ & \\
\hline 1 & Tenaga kerja 1 & & & & & & & & & \\
\hline 2 & Tenaga kerja 2 & 15 & 10 & 7 & 7 & 6 & 3 & 7 & 5 & 60 \\
\hline 3 & Tenaga kerja 3 & & & & & & & & & \\
\hline
\end{tabular}

Keterangan:

A = Tenaga yang dikeluarkan

$\mathrm{B}=$ Sikap kerja
$\mathrm{C}=$ Gerakan Kerja

$\mathrm{D}=$ Kelelahan

$\mathrm{E}=$ Keadaan temperature tempat kerja

$\mathrm{F}=$ Keadaan Atmosfer

$\mathrm{G}=$ Keadaan lingkungan yang baik

$\mathrm{H}=$ Kebutuhan Pribadi

Angka yang didapat dari tabel 8 diatas, yang mana angkaangka tersebut telah di ketahui berapa nilanya masingmasing. Setelah diketahui Performance Rating dan Allowance maka dapat dihitung beban kerja untuk masingmasing tenaga kerja bahan baku dengan menggunakan formula berikut ini:

Beban Kerja $=$

$\%$ produktif $x$ performance rating $x$ Emenit pengamatan $x(1+$ allowance $)$ $=\frac{89,57 \times 1,31 \times 3990 \times 1,60}{3990}=187,74 \%$

Dari perhitungan ini maka dapat di ketahui beban kerja masing-masing elemen kerja seperti pada tabel 9 dibawah ini.

Tabel 9. Beban Kerja Masing-Masing Elemen Kerja

\begin{tabular}{|c|c|c|c|c|c|}
\hline No & $\begin{array}{c}\text { Jabatan } \\
\text { Struktural }\end{array}$ & $\begin{array}{c}\text { Produktif } \\
(\%)\end{array}$ & $\begin{array}{c}\text { Performance } \\
\text { Rating }(\mathrm{P})\end{array}$ & $\begin{array}{c}\text { Allowance } \\
(\%)\end{array}$ & $\begin{array}{c}\text { Beban } \\
\text { Kerja (\%) }\end{array}$ \\
\hline 1 & $\begin{array}{l}\text { Tenaga } \\
\text { Kerja } 1\end{array}$ & 89,57 & 1,31 & 1,60 & 187,74 \\
\hline 2 & $\begin{array}{l}\text { Tenaga } \\
\text { Kerja } 2\end{array}$ & 89,57 & 1,27 & 1,60 & 182,01 \\
\hline 3 & $\begin{array}{l}\text { Tenaga } \\
\text { Kerja } 3 \\
\end{array}$ & 89,57 & 1,28 & 1,60 & 183,44 \\
\hline & \multicolumn{4}{|c|}{ Total } & 548,19 \\
\hline
\end{tabular}

Berdasarkan tabel 9 diatas, Allowance ini ada beberapa faktor yang mempengaruhinya yaitu tenaga kerja 1 persentase produktifnya $89,57 \%$, Performance Rating 1,31, Allowance 1,60 \%, dengan beban kerja187,74\%, tenaga kerja 2, persentase produktifnya 89,57\%, Performance Rating 1,27, Allowance 1,60\%, dengan beban kerja $182,01 \%$, tenaga kerja 3 presentase produktifnya 89,57 \%, Performance Rating 1,28, Allowance 1,60 \%, dengan beban kerjanya183,44 \% sehingga total keseluruhan beban kerja adalah 548,19\%. Untuk mendapatkan hasil dari persentasi produktif dari jumlah persentasi produktif 30 hari yaitu 89,87\%, sedangkan Perfomance Rating nya didapat dari total perfomance yang berdasarkan weshtinghouse, angka Allowance nya didapat dari total Allowance berdasarkan faktor-faktor yang berpengaruh, total dari masing - masing tenaga kerja dikalikan dengan masing-masing persentasi produktif, Performance Ranting, Allowance.

\section{Perhitungan Jumlah Tenaga Kerja Yang Optimal}

Rata-rata beban kerja bagian kebun adalah tinggi sehingga pada bagian kebun ini memerlukan penambahan tenaga kerja. Untuk menentukan jumlah tenaga kerja yang optimal dapat diformulasikan sebagai berikut: 
Rata-rata beban kerja pada bagian kebun:

1. Total beban kerja

$=187,74 \%+182,01 \%+183,44 \%$

$=548,19 \%$

Rata-rata beban kerja (kondisi rill)

$\frac{548,19 \%}{3}=182,73 \%$

2. Rata rata beban kerja (usulan)

Dapat dilihat dari perhitungan diatas bahwasanya ratarata beban kerja untuk tenaga kerja pada bagian kebun melebihi $100 \%$, maka dari itu perhitungan beban kerja usulan sebagai berikut:

$$
\frac{5553,18 \%}{100 \%}=5,53 \text { orang }
$$

Berarti penambahan tenaga kerja yang ideal sebanyak 6 orang tenaga kerja karena menurut (Anggara, 2012) beban kerja yang baik mendekati $100 \%$, pada bagian kebun ini karena bilangan harus dibulatkan keatas. Dan perhitungan rata-rata beban kerja sebagai berikut:

$\frac{553,18 \%}{6}=92,19 \%$

Bisa dilihat dari perhitungan diatas bahwa beban kerja ratarata pada kondisi rill sebesar 553,18\% angka tersebut melebihi $100 \%$. Setelah dilakukan perhitungan jika di tambah 3 orang tenaga kerja menjadi 6 orang tenaga kerja maka rata-rata beban kerja yang di dapatkan menjadi 92,195 telah memenuhi standar yang mana tidak melewati angka $100 \%$. Setelah dilakukan perhitungan Maka sebaiknya jumlah tenaga kerja pada bagian kebun ditambah menjadi 6 orang tenaga kerja dengan rata-rata beban kerja sebesar 92,19\%. Yang mana beban kerja yang baik, sebaiknya mendekati $100 \%$ dalam kondisi normal. Beban kerja $100 \%$ tersebut, berarti bahwa selama 7 jam pekerja mampu bekerja secara terus menerus dalam kondisi yang normal. Semakin tinggi beban kerja maka semakin tinggi biaya yang di butuhkan oleh tenaga kerja, biayanya seperti gaji tenaga kerja, upah lembur tenaga kerja dan biaya kesehatan bagi tenaga kerja. Total gaji yang diperoleh tenaga kerja 1 berjumlah 8 orang, tenaga kerja 2 berjumlah 8 orang, dan tenaga kerja 3 berjumlah 8 orang jadi semua total tenaga kerja berjumlah 24 orang Total gaji perbulannya berjumlah Rp 57.600.000. karena tenaga kerja mengalami beban kerja yang tinggi maka solusinya yaitu menambah tenaga kerja atau mengadakan lembur. jadi total tenaga kerja yang lembur berjumlah 16 orang, dan upahnya berjumlah Rp 31.360.000 per bulanya. Jika ditotalkan semuanya gaji dan upah lembur, perusahaan mengeluarkan biaya berjumlah Rp 88.960.000. selanjutnya jika perusahaan menambah tenaga kerja total pekerja 1 berjumlah 3 orang tenaga kerja 2 berjumlah 3 orang dan tenaga kerja 3 berjumlah 3 orang total semuanya berjumlah 9 orang maka perusahaan mengeluarkan biaya berjumlah Rp 21.600.000 lalu dijumlahkan dengan tenaga kerja yang lama jadi total semuanya berjumlah Rp 79.200.000. setelah dilakukan perhitungan lebih baik menambah tenaga kerja karena perusahaan tidak terlalu banyak mengeluarkan dana dan tenaga kerjapun tidak merasakan beban yang terlalu tinggi.

\section{KESIMPULAN}

Berdasarkan pembahasan yang telah dilakukan, maka dapat diambil kesimpulan bahwa perhitungan dan analisis Analisis Beban Kerja dan Jumlah Tenaga Kerja Pada Bagian Bahan Baku Dengan Menggunakan Metode Workload Analysis (WLA) Pada PT. XYZ didapatkan hasil dimana beban kerja tenaga kerja 1 sebesar 187,74\%, tenaga kerja 2 sebesar 182,01\% dan tenaga kerja 3 sebesar $183,44 \%$, sehingga total keseluruhan beban kerja adalah $548,19 \%$ dengan rata-rata beban kerja 182,73\% dalam kondisi rill. Jadi beban kerja yang didapat oleh semua tenaga kerja bagian kebun melebihi angka 100\%. Ini artinya beban kerja yang terlalu tinggi maka perlu adanya penambahan tenaga kerja yang ideal sebanyak 6 orang tenaga kerja untuk menggurangi beban kerja terlalu tinggi. Ini artinya beban kerja yang terlalu tinggi maka perlu adanya penambahan tenaga kerja yang ideal sebanyak 6 orang tenaga kerja untuk menggurangi beban kerja terlalu tinggi. Dengan penambahan tenaga kerja maka beban kerja menjadi 92,19\% dan telah memenuhi standar.

\section{DAFTAR PUSTAKA}

Arif, R. Analisa Beban Kerja dan Jumlah Tenaga Kerja Yang Optimal Pada Bagian Produksi Dengan Pendekatan Metode Work Load Analysis (Studi Kasus: PT. Surabaya Perdana Rotopack). Jawa Timur: Jurnal Teknik Industri Universitas Pembangunan Nasional "Veteran.2014.

Astianto, A. dan Suprihhadi, H. Pengaruh Stres Kerja dan Beban Kerja Terhadap Kinerja Karyawan PDAM Surabaya. Jurnal Ilmu \& Riset Manajemen Vol. 3 No. 7, pp $1-8.2014$

Lituhayu, Rizaini. Mangkuprawiru, Tb Sjafri. Dhewi, Ratih Maria. Analisa Beban Kerja dan Kinerja Karyawan (Studi Kasus Pada Head Office PT. Lerindo Internasional Jakarta). Sarjana, Skripsi. Institut Pertanian Bogor.2008.

Prabowo, A., dkk. Analisa Beban Kerja dan Penentuan Tenaga Kerja Optimal dengan Pendekatan Work Load Analysis (WLA). Jurnal Teknik Industri Vol. 5 No. 1, pp 3. 2017.

Rafian, Ade Muhammad dan Ahmad Muhsin. Analisis Beban Kerja Mekanik Pada Departemen Plant dengan Metode Work Sampling, Jurnal OPSI, Vol 10 No 1 Juni 2017, hlm 35-42, dapat diakses di http://jurnal.upnyk.ac.id/index.php/op si/article/download/2165/1905. 2017.

Wakhinuddin. Pengertian Evaluasi, Beban Kerja, Optimalisasi. Webblog.com. 
Http///www.wakhinuddin.weblog//pengertianevalu asibabankerjaoptimalisasi.com (diakses 8 desember 2017).

Wakui, Tadaaki. Study On work Load Of Matron Under shift A Special Nursing Home For The Elderly, Journal of Industrial Health, www.niih.go.jp/en/indu_hel/2000pdf/IH38_36.pdf. 2010.

Wibawa, R. P. N., Sugiono, S., \& Efranto, R. Y. Analisis Beban Kerja Dengan Metode Workload Analysis Sebagai Pertimbangan Pemberian Insentif Pekerja (Studi Kasus di Bidang PPIP PT Barata Indonesia (Persero) Gresik). Jurnal Rekayasa Dan Manajemen Sistem Industri, 2 (3), p672-683. 2014

Wignjosoebroto, S. Ergonomi studi gerak dan waktu. Surabaya: Guna Widya,2003,pp, 283. 